\title{
Kernos
}

Revue internationale et pluridisciplinaire de religion grecque antique

12| 1999

Varia

\section{The Death of Zeus Kretagenes}

\section{N. Postlethwaite}

\section{Journals}

\section{Electronic version}

URL: http://journals.openedition.org/kernos/711

DOI: 10.4000/kernos.711

ISSN: 2034-7871

\section{Publisher}

Centre international d'étude de la religion grecque antique

\section{Printed version}

Date of publication: 1 January 1999

Number of pages: 85-98

ISSN: 0776-3824

Electronic reference

N. Postlethwaite, "The Death of Zeus Kretagenes », Kernos [Online], 12 | 1999, Online since 13 April 2011, connection on 01 May 2019. URL : http://journals.openedition.org/kernos/711 ; DOI : 10.4000/ kernos.711

Kernos 


\section{The Death of $\mathbb{Z}$ eus $\mathbb{K r e t a g e n e s}$}

Since its inception in 1988 , contributors to Kernos have frequently been drawn to the subject of Cretan Zeus. In its inaugural volume, J.A. Sakellarakis ${ }^{1}$ welcomed the resumption of the investigation of the Idaean cave on Psiloritis by the Archaeological Society of Athens. He was able to claim that this investigation had made available, for the first time, evidence that the Minoans had used the cave for religious purposes from the Early, through the Middle, and into the Late Minoan periods: and there was there, he declared, "explicit and unquestionable" evidence that the "origin of the singular worship of Cretan Zeus, the god who was born and died every year, lies in the prehistoric, Minoan deity, the young god who personified the yearly birth and death of the vegetation cycle"2.

Subsequently E.F. Bloedow ${ }^{3}$ focused on another Cretan peak, Mt. Iouktas, and in particular on its peak sanctuary, which was investigated by Evans in 1909 and reported by him in The Palace of Minos at Knossos ${ }^{4}$. Bloedow argued that the sanctuary had housed the cult of Cretan Zeus, against Evans' contention that it had been the sanctuary of the cult of the Great Mother Goddess: he did so by pointing to the lack of primary evidence to support Evans' claim, and by referring to the recent re-investigation of the site by A. Karetsou ${ }^{5}$. In particular, Bloedow drew attention to the natural chasm, which descends between the two terraces of the sanctuary and which was excavated by Karetsou to a depth of $10.50 \mathrm{~m}$., and to the altar which was positioned at its entrance; and he asked "given the long tradition of the site as the 'tomb of Zeus', what place could be more suitable as the burial spot of Cretan Zeus, who dies annually and is reborn annually?". In particular, he claimed that "this becomes all the more plausible, given the famous nature of the myth, and the enduring character of the tradition asso-

1 J.A. Sakellarakis, The Idaean Cave. Minoan and Greek Worship, in Kernos, 1 (1988), p. 207-214.

2 Sakellarakis, ibid, p. 212.

3 E.F. BLoEdow, Evidence for an Early Date for the Cult of Cretan Zeus, in Kernos, 4 (1991), p. 139-177.

4 A.J. Evans, The Palace of Minos at Knossos 1, London, 1921, p. 151-163.

5 A. Karetsou, The Peak Sanctuary of Mt. Juktas, in R. HägG \& N. Marinatos (eds.), Sanctuaries and Cults in the Aegean Bronze Age, Stockholm, 1981, p. 137-153. 


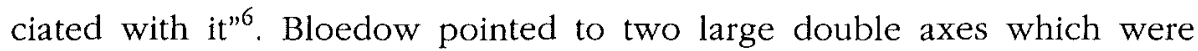
discovered in the vicinity of the altar and, recalling Burkert's demonstration that "the double axe is a symbol of power, the power to kill" , and declaring the two axes to be of a size suitable for bull-slaughter, he argued that the likelihood was that a boupbonia was a feature of the cult; and so he suggested that "the slaying of the bull in the original cult presumably symbolised the dying of Zeus"8. Since the double axe is such a recurring motif in Minoan culture, and particularly in view of the presence of thirty-two smaller examples (0.12-0.09 $\mathrm{m}$. long) found in the immediate vicinity and apparently having only a symbolic function, it remains open to doubt whether Bloedow is justified in thus attaching a practical significance to these two larger ones. Yet the presence of quantities of animal bones in the nearby structure at Anemospilia, designated a 'temple' by its excavators (discussed below), certainly suggests regular animal sacrifice. Since the altar and the double axes are dated to the Old Palace stratum, Bloedow concluded that "we may therefore now also envisage the existence of an independent, specific cult of Cretan Zeus going back to at least the MM I A period"?.

The tradition of the birth of Zeus in the island of Crete was established by the time of Hesiod: it told that his mother Rhea was brought to Lyktos to give birth to him and that she deceived his father Kronos, who had devoured all their offspring, by giving him a stone in place of her last-born ${ }^{10}$. In addition, however, there was a persistent tradition suggesting, not merely the birth, but rather the rebirth, of a deity who also died, as a youth, each year. For example, Antoninus Liberalis 19 tells that:

'In Crete there is said to be a sacred cave full of bees. In it, as storytellers say, $/$ Rhea gave birth to Zeus; it is a sacred place and no one is to go near it, whether / god or mortal. At the appointed time each year a great blaze is seen to come out / of the cave. Their story goes on to say that this happens whenever the blood from / the birth of Zeus begins to boil up'. ${ }^{11}$

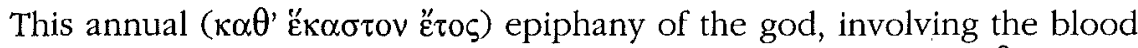

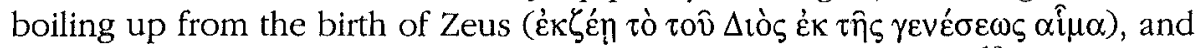
the accompanying blaze from the cave are interpreted by West $^{12}$ as symbolic of the return of the rising sap to vegetation at the onset of spring. The passage contains no reference to the subsequent death of the deity but, if the event recorded by Antoninus is indeed the vernal appearance of the god of

\footnotetext{
BLoedow, loc. cit. (n. 3), p. 163.

W. BuRKerT, Greek Religion, Archaic and Classical, Oxford, 1985, p. 38.

8 Bloedow, loc. cit. (n. 3), p. 163.

9 Bloedow, loc. cit. (n. 3), p. 169.

10 HEs., Th., 453-491.

11 F. Celoria, The Metamorphoses of Antonimus Liberalis, London, 1992, p. 74.

12 M.L. WEST, The Dictaean Hymn to the Kouros, in JHS, 85 (1965), p. 149-159.
} 
vegetation, then such would be the natural consequence to symbolise the dying season.

In the Diktaian Hymn to the Kouros, which was discovered at the site of the temple of Zeus Diktaios at Palaikastro, the addressee is implored (1-6):

Io! Greatest Kouros,

hail, son of Kronos,

master of all, who to earth art gone

with the powers in train, now come again

to Dikte at the year's wend

and hear with gladness our refrain!

Although not actually addressed as Zeus, it seems clear from the invocation that the Kouros is to be identified with him ('son of Kronos'). In the third

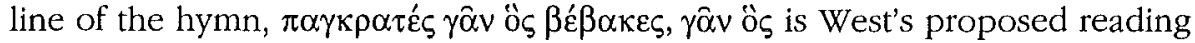

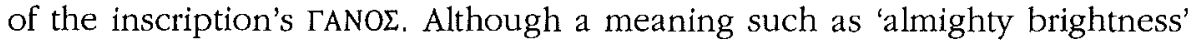
for $\gamma$ óvos would add a further title to the invocation of the Kouros - 'greatest Kouros, master of all, almighty brightness' - , as West points out, it leaves the verb $\beta \varepsilon \hat{\varepsilon} \beta \alpha \kappa \varepsilon \varsigma$ isolated, resulting in a declaration that the deity has gone but with no indication given of his destination. West's proposed reading provides just such a destination in $\gamma \hat{\alpha} v$, and, together with the prayer that he 'come

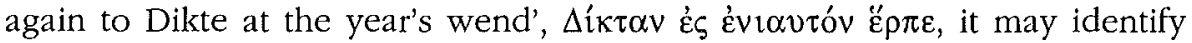
him as a deity of nature who dies with the end of the year and is reborn with its renewal. West concludes that "while Zeus accepted from the Kouros the condition of death, the Kouros, under the influence of Zeus, renounced the ignominy of dying, and became like Kore an immortal who 'went to earth' and returned each year"13.

Thirdly, in his Life of Pytbagoras, Porphyry recounts that Pythagoras put in at Crete whilst on a journey to Italy; he descended into the Idaian Cave, spent thrice nine days there, made sacrifice to Zeus, and viewed the throne which was spread for the deity 'each year'; he claims too that Pythagoras inscribed an epigram, 'Pythagoras to Zeus', on the god's tomb, which began

Here lies dead Zan, whom men call Zeus ${ }^{14}$.

Whilst it is clearly essential to be circumspect in thus conflating sources which range from the $4 \mathrm{th} / 3 \mathrm{rd}$ centuries $\mathrm{BC}$ to the 3 rd century $\mathrm{AD}$, we should note that in each of the three there is the suggestion of an annual ritual and, in the case of Porphyry and (West's emendation of) the Hymn to the Kouros, the suggestion of the god's death also. Equally, however, we should note that in none is there any indication of the manner of his death.

13 Ibid., p. 159.

14 Porph., Vita Pyth., 17; cf. M. Kokolakrs, Zeus' Tomb. An Object of Pride and Reproacb, in Kernos, 8 (1995), p. 124. 
It has been generally accepted that this picture of Zeus in Crete, as a deity who embraces both life and death each year, was derived from a preHellenic, Minoan, cult of the dying god, which was itself closely associated with the central role in Minoan culture of the figure of the Mother Goddess, although this suggestion of a pre-Hellenic origin has been challenged recently by $H$. Verbruggen ${ }^{15}$. In this paper I wish to support this traditional account of Cretan Zeus, by associating with it evidence provided by the excavations at the site of Anemospilia, below the summit of Mt. Iouktas, which I suggest may make a substantial contribution to our understanding of the cult.

Whilst the claim of Crete to be the birthplace of Zeus was widely accepted (though a claim was also made for Mt. Lykaion in Arcadia), the myth that the god also died and was buried in the island was unique to Crete, and indeed was dismissed by outsiders as sure evidence of Cretan mendacity. The most famous account of the myth is found in Callimachus' Hymn to Zeus:

How shall we sing of him [Zeus] - as lord of Dicte or of Lycaeum? My soul is all in doubt, since debated is his birth. O Zeus, some say that thou wert born on the hills of Ida; others, O Zeus, say in Arcadia; did these or those, O Father, lie?

"Cretans are ever liars".

Yea, a tomb, O Lord, for thee the Cretans builded; but thou didst not die, for thou art for ever ${ }^{16}$.

The source of the gnomic "Cretans are ever liars" has generally been taken to be the Cretan Epimenides; however, it is unclear whether the words in the Hymn are to be taken as spoken by him, or by Callimachus himself, or indeed by Zeus ${ }^{17}$. The Scholia to the Hymn attempted to rationalise this strange tale of Zeus' burial thus:

In Crete on the tomb of Minos was inscribed The Tomb of Minos Son of Zeus. In time the words Minos Son of were erased, so that what remained was The Tomb of Zeus ${ }^{18}$.

The tomb itself was variously located: in the region of Knossos; within the Idaian Cave; and on Mt. Dikte ${ }^{19}$. However, until the visit to the area by C. Buondelmonti in $1415^{20}$, there seems to have been no recorded association

15 H. Verbruggen, Le Zeus Crétois, Paris, 1981.

16 Callim., Hymns, 1, 4-9: A.W. Mair (tr.), Callimachus and Lycopbron, Loeb, 1921.

17 N. Hopkinson, Callimachus'Hymn to Zeus, in CQ, 34 (1984), p. 140.

18 References to the death and burial of Zeus are collected by A.B. Cook, Zeus. A Study in Ancient Religion, Cambridge, 1925, ii, p. 940-943, and are discussed in detail by Kokolakis, loc. cit. (n. 14).

19 Kokolakis, loc. cit. (n. 14), p. 125.

20 Cf. P. Faure, Le Mont Jouktas, tombeau de Zeus, in Minoica. Festschrift Ioh. Sundwall, Berlin, 1958, p. 133-148. 
of the tomb with Mt. Iouktas, even though this became the popular location in later times.

The Cretan tale of the dying Zeus recalls the stories of other dying gods, most notably Adonis and Attis. The story of Adonis and Aphrodite was adapted from that of the Akkadian Tammuz and Ishtar (which was itself derived from the story of Sumerian Dumuzi and Inanna). In the Mesopotamian myth the young consort Tammuz/Dumuzi died in representation of the dying season and was mourned by the Mother Goddess figure Ishtar/Inanna ${ }^{21}$; similarly Adonis too died, as described in the version of Apollodorus which begins with the story of his mother Smyrna:

In consequence of the wrath of Aphrodite, for she did not honour the goddess, / this Smyrna conceived a passion for her father, and with the complicity of her / nurse she shared her father's bed without his knowledge for twelve nights. But / when he was aware of it, he drew his sword and pursued her, and being overtaken / she prayed to the gods that she might be invisible; so the gods in compassion turned/her into the tree which they call smyrna (myrrh). Ten months afterwards the tree / burst and Adonis, as he is called, was born, whom for the sake of his beauty, while / he was still an infant, Aphrodite hid in a chest unknown to the gods and entrusted / to Persephone. But when Persephone beheld him, she would not give him back. / The case being tried before Zeus, the year was divided into three parts, and the god / ordained that Adonis should stay by himself for one part of the year, with Persephone / for one part, and with Aphrodite for the remainder. However Adonis made over to / Aphrodite his own share in addition; but afterwards in hunting he was gored and / killed by a boar ${ }^{22}$.

Bion $^{23}$ records that Adonis took the fatal wound from the boar in his thigh; Ovid ${ }^{24}$ on the other hand says it was in the groin, which seems to reflect a version in which Adonis may have suffered emasculation by the boar ${ }^{25}$.

Another dying god was Attis, of whose story there are two versions, both of which are recorded by Pausanias ${ }^{26}$, who names as his source the elegiac poet Hermesianax:

...that Attis migrated to Lydia and celebrated for the Lydians the orgies of the Mother; that he rose to such honour with her that Zeus, being wroth at it, sent a boar to destroy the tillage of the Lydians. Then certain Lydians, with

21 For discussion of the myth, see J.D. ReED, The Sexuality of Adonis, in ClAnt, 14 (1995), p. 317-347.

22 Apollod., III, 14, 4: J.G. Frazer (tr.), Apollodorus: The Library, Loeb, 1921.

23 BION, 1, 7-8,

24 OvID, Metam., X, 715; cf. Amores, III, 9, 16.

25 REED, loc. cit. (n. 21), p. 335.

26 Paus., VII, 17, 9-11: W.H.S. Jones (tr.), Pausanias: Description of Greece, Loeb, 1933. 
Attis himself, were killed by the boar ... But the current view about Attis is different, the local legend about him being this. Zeus, it is said, let fall in his sleep seed upon the ground, which in course of time sent up a demon, with two sexual organs, male and female. They call the demon Agdistis. But the gods, fearing Agdistis, cut off the male organ. There grew up from it an almond-tree with its ripe fruit, and a daughter of the river Sangarius, they say, took of the fruit and laid it in her bosom, when it at once disappeared, but she was with child. A boy was born, and exposed, but was tended by a hegoat. As he grew up his beauty was more than human, and Agdistis fell in love with him. When he had grown up, Attis was sent by his relatives to Pessinus, that he might wed the king's daughter. The marriage-song was being sung, when Agdistis appeared, and Attis went mad and cut off his [own] genitals, as also did he who was giving him his daughter in marriage.

An interesting variant of the story of Attis is given by Herodotus, who tells of the divine punishment which befell Croesus: after entertaining Solon, and after giving him a conducted tour of his treasures, Croesus invited him to recall whether in the course of his travels Solon had ever encountered a man blest beyond all men; but when Solon failed to include Croesus amongst his catalogue of the blest, he was rudely dismissed by him; and in consequence divine nemesis fell upon Croesus. Herodotus recounts that Croesus had a dream that his son, who was named Atys, would be killed by an iron spear. To guard against this, Croesus forbade his son to take part in any military exercise, removed all javelins and spears from the men's apartments lest one fall upon his son by accident, and even married his son off in order to provide him with distractions from military pursuits. In time a great boar appeared, which ravaged the territory of the Mysians; Atys at last secured his father's permission to join the boar-hunt, on the grounds that Croesus' dream had said nothing of death by boar's tusk; but after the huntsmen formed themselves into a circle around the boar, Atys was fatally wounded by a misdirected spear-cast from one Adrastus, a grandson of Midas, whom Croesus had received into his home as a suppliant and purified ${ }^{27}$. For all that Herodotus' tale contains a variant spelling of the name Attis, and for all that the story seems to have been rationalised in keeping with the more 'historical' setting, nevertheless the fundamentals of the Attis story remain intact.

Once again we should be hesitant in assembling sources which range from the second millenium $\mathrm{BC}$ to the second century $\mathrm{AD}$; nevertheless we observe not merely the fact of the deaths of Adonis and Attis, but also the common element of the death-dealing boar, coupled with the element of self-emasculation or emasculation by the boar.

It is an extraordinary fact that, amongst the many references to the death and burial of Zeus in Crete which were collected by Cook (see note 18),

27 HERM., 1, 30-43. 
none in fact gives an account of the death itself: the sources accept the fact (or the fiction) of the death, but are exercised rather by the location of the burial. For an allusion to the manner of Zeus' death it is necessary to turn to Isho'dad, a follower of Nestorius, in his Commentary on the Acts of the Apostles, who claimed as his source Theodore of Mopsuestia; in his note on Acts 17.28 Isho'dad reports:

The Cretans said about Zeus, as if it were true, that he was a prince, and was lacerated by / a wild boar, and was buried; and behold! his grave is known amongst us; so Minos, the son / of Zeus, made a panegyric over his father, and in it he said

"The Cretans have fashioned a tomb for thee, O Holy and High!

Liars, evil beasts, idle bellies;

For thou diest not; for ever thou livest and standest;

For in thee we live and move and have our being"28.

In this account of his death, Zeus appears to be associated with the deaths of Adonis and Attis, not merely in the reported fact of his death, but in its violent nature also, and in particular in the instrumentality of the wild boar. Since Isho'dad himself in the ninth century AD, and his source Theodore in the $4 \mathrm{th} / 5$ th century $\mathrm{AD}$, are so far removed from the legend which they purport to recall, we should have even greater reservations than in the case of the sources recorded above and acknowledge the probable aetiological nature of the story: granted the claim of the Cretans (albeit a claim dismissed by all other Greeks) that Zeus died in their island, the need to account for it might well have led to its association with the tales of other dying gods. Nevertheless the possibility that Isho'dad's story may in fact reflect an earlier belief has, I will try to demonstrate below, been enhanced by the recent archaeological discovery of evidence suggesting the involvement of the boar in the cult practice of Minoan Crete.

The remarkable discovery, made at the site of Anemospilia in 1979 by J. and E. Sakellarakis, of what the excavators have interpreted as a human sacrifice, has recently been made available to a wide audience ${ }^{29}$ and there is consequently little need to give more than a broad outline here. In relation to the myth of the dying Zeus, the nature and location of the site are of significance, on the northern slopes of Mt. Iouktas about $400 \mathrm{~m}$. below its summit, "on a small tongue of land jutting out precisely at the point where the rocky mountain bed and cultivable land start to converge" ${ }^{30}$, and beside the road

28 Cook, op. cit. (n. 18), i, p. 663.

29 J.A Sakellarakis \& E. Sapouna-Sakellaraki, Arcbanes, Athens, 1991, p. 137-156; an earlier account in English has been available for some time in Drama of Deatb in a Minoan Temple, in National Geograpbic (Feb. 1981), p. 205-222; a full account in Greek of the excavation was given in J.A. \& E. Sakellarakis, 'A $\alpha \alpha \sigma \kappa \alpha \phi \dot{\eta}$ 'A $\rho \chi \alpha \nu \omega \nu$, in PAAH (1979), p. 331-392.

30 Op. cit., p. 137. 
from the major palace site of Archanes to the peak shrine on the mountain's summit. Because the structure excavated is the sole structure on the site, and because the remains of a temenos wall were discovered at its southern edge, the excavators have had no reservation about identifying the structure as a temple, the earliest temple of Minoan Crete. MM II and MM III A pottery discovered in the ruins of the structure indicate that it was destroyed in the first half of the 17 th. century $\mathrm{BC}$, and the ruins indicate that the cause was a devastating earthquake followed by an intense conflagration. The structure comprises three rooms without connecting doors, on an east-west axis facing north; each chamber has a door opening on its north side into a connecting corridor, which has been described as a prothalamos. It appears that there may have been three matching chambers on the opposite side of the corridor, and that there was an upper storey from which substantial debris fell during the building's collapse.

In the corridor were found the fragments of some 155 vessels, many containing the remains of fruits, grains, and pulses. A human skeleton, crushed beyond recognition by falling masonry, was found in close association with fragments of a Kamares-ware vase decorated with a bull motif. It was suggested that bull sacrifice was a part of the rituals enacted in the building, and that its preparation, and that of other offerings, took place in the prothalamos; the remains suggested a hurried attempt to evacuate the corridor at the moment of destruction. The east chamber contained a stepped altar on its southern wall, and the discovery of large quantities of vessels associated with the remains of fruits and grains indicated that the chamber's function was to house bloodless offerings. In the central chamber also there was a raised area on the southern wall, on which there rested two life-sized clay feet with their ankles shaped as a dowel, suggesting that they had acted as supports for a xoanon, a wooden statue, and the presence of an ash deposit confirmed this as their function. A mound of natural rock in this central chamber indicated that the deity most likely represented by the xoanon was the Earth Mother, and that the function of this chamber was to house her cult statue. Finally in the third, west, chamber were discovered three skeletons whose configuration suggested to the excavators that the earthquake had interrupted, and preserved in the most fortuitous fashion, a ritual involving human sacrifice. The first skeleton, found in the SW corner of the chamber, was that of a female aged approximately 28; the skeleton was lying face down and was badly crushed by falling masonry, and the bones were blackened by the ensuing fire. A second skeleton was found by the west wall of the chamber, that of a male aged approximately 38 ; he was lying on his back with hands raised as though in an instinctive gesture of fending off falling masonry; this skeleton too was badly crushed and blackened. On the little finger of his left hand he was wearing a ring of silver and iron, the latter a most valuable commodity, indicating its owner as a person of considerable importance. He was also wearing an agate sealstone portraying a male figure punting a boat of which the prow was fashioned in the shape of 
a bird. A third skeleton was found lying on an elevated area, artificially constructed from stones bound by a clay cement; this was the skeleton of a male aged approximately 18 years, and its configuration, lying on its side with left leg bent back so that the heel was almost in contact with the back of the thigh, suggested to the excavators that the young man may have been bound at the time of his death. This skeleton was even more badly crushed than the others, and across the torso lay a bronze blade $40 \mathrm{~cm}$. in length and weighing 633 grams. The blade was originally described by the excavators as a knife, but the presence of two attachment slots has subsequently caused them to entertain the suggestion that it may in fact be a lance of some description ${ }^{31}$. The fact that the bones on the lower, right, side of the skeleton had been blackened by the ensuing fire, whereas those on the upper, left, side were of a much lighter colour was, the excavators were advised, an indication that the young man had perished, not in the earthquake but as a result of blood loss prior to the conflagration.

The discoveries at Anemospilia have been declared by their excavators to present unequivocal evidence for the ritual of human sacrifice. The presence elsewhere in the building of animal bones, as well as the remains of fruits and grains, marked the structure as a place of blood and bloodless sacrifice; the remains of the cult idol in the central chamber indicated the likely recipient of the offerings; the presence of an apparently healthy 18 year old lying bound on a structure taken to be an altar (with the possibility that a wooden structure was mounted upon the artificial stone area), with an ornate blade resting across his upper torso, indicated the victim; and the presence in the chamber of two further individuals, identified as priest and priestess by the excavators, indicated the perpetrators of the deed, particularly in view of the distinctive sealstone worn by the male, with its representation of a man punting a boat, which was suggestive of the final journey of the dead, transported by a Charon-like figure. That the participants should, exceptionally, on this occasion have turned from the norm of animal and/or bloodless sacrifice to the extreme of human sacrifice was to be explained by the nature of the destruction: in effect, the young male victim was a scapegoat, a pharmakos, by whose death it was hoped to ward off the very earthquake which brought about the destruction of the building and sealed in its unique contents.

The interpretation of the discoveries at Anemospilia offered by Sakellarakis and Sapouna-Sakellaraki, and their (at times) vivid reconstruction of events accompanying the destruction of the building, have, not surprisingly, been challenged by D.D. Hughes ${ }^{32}$ and, more recently, by P. Bonnechere ${ }^{33}$. Hughes has questioned both the details and their proposed interpretation: he has disputed the claim that bull sacrifice could have occur-

31 Op. cit., p. 132.

32 D.D. Hughes, Human Sacrifice in Ancient Greece, London, 1991.

33 P. BONNECHERE, Les indices archéologiques du sacrifice bumain grec en question: compléments à une publication récente, in Kernos, 6 (1993), p. 23-55. 
red within such a confined and congested building, and in particular within the corridor where the presence of large quantities of pottery would have rendered such activity impossible; he has disputed the identification of the artificial structure on which the skeleton of the 18 year old was resting as an altar, on the grounds that it bears no resemblance to representations of the structures on which animal sacrifice takes place, such as on the Hagia Triadha sarcophagus where the beast is strapped down on a table-like structure; and he has disputed that the variations in discolouration of the young man's bones are to be explained by the suggestion that the blood was draining from his body, and accepts rather the explanation that different parts of the body were exposed to varying degrees of intensity of heat from the conflagration which followed the earthquake; finally, Hughes suggests that the position of the young man's body may as well be explained as an accident, that he tripped during the general confusion accompanying the earth tremors, coming to rest, as he was found, on the elevated area, and that the presence of the blade across his torso was similarly accidental, having perhaps fallen from a wall or from the upper storey during the building's collapse ch $^{34}$.

In turn, $\mathrm{P}$. Bonnechere has attempted to reinforce Hughes' doubts: because of the restricted area, he too denied that animal sacrifice could have been the norm in the Anemospilia building, replaced on this occasion by the supposed human sacrifice because of the exceptional circumstances of the moment; he too disputes the identification of the altar on which the young man was lying; he suggests that the presence of the blade across the torso may be explained as a weapon which the young man was carrying or even wearing "attachée à sa ceinture"; and he too accepts variation in exposure to the fire as explanation of variation in discolouration of the bones. Bonnechere concludes "il n'existe, au demeurant, aucune raison de favoriser cette [Sakellarakis'] thèse vis-à-vis de celles qui, de façon moins extraordinaire mais plus plausible, envisagent le décès accidentel des trois personnes incriminées" 35 .

In their objections, both Hughes and Bonnechere have, quite correctly, concentrated upon the details of the excavation and their interpretation. In fact, however, a further objection might be raised, with perhaps even greater validity, on the question of the motive for the human sacrifice which was proposed by the excavators. In view of the familiarity which, it may reasonabiy be assumed, the inhabitants of the island had with the (at times) devastating impact of earthquake upon person and place, it is, at the very least, a surprising suggestion that at a time of earthquake the participants in this ritual should have undertaken it within the structure ${ }^{36}$, assuming, that is, that

HuGHES, op. cit. (n. 32), p. 13-17.

36 Sakellarakis \& Sapouna-Sakellaraki, op. cit. (n. 29), p. 156. 
they had been given prior warning of the earthquake's imminence. Yet it is an equally unlikely suggestion that such an amount of warning was given. The site of the structure is itself remote, lying some $3 \mathrm{~km}$. from the major centre of population at Archanes, and it seems highly unlikely that this, or any other, earthquake would have given sufficient warning to allow the transportation of the, possibly unwilling, victim half way to the summit of Mt. Iouktas; and even if sufficient warning had been given, the ritual would surely have taken place out of doors in order to avoid precisely the experience which befell the unfortunate victims. The only alternative would seem to be the suggestion that everything, including the intended victim, was already in place on the mountainside in anticipation of the moment when earthquake might strike. It seems more realistic to conclude either, with Hughes and Bonnechere, that no sacrifice was taking place and that we must suppose that the four victims of the earthquake were simply going about their daily business within the building; or, with the excavators, that a sacrifice was indeed taking place, but for a different purpose than they supposed.

In their most recent account of their discoveries, the excavators have taken some notice of possible objections: they have, for example, attempted to accommodate the observation that, as excavated, the stone elevation on which the victim was lying bears no resemblance to illustrations of animal sacrifice, by suggesting that he may have been lying on a wooden structure above the artificial stone level. However, despite objections, they have insisted on their explanation of the variation in the discolouration of the skeletons found, and their account of the manner of death of the young man: "death occurred subsequent to the severing of the extended jugular carotid in the left part of the neck. The Minoans knew from bull sacrifices that this was the point from which the most amount of blood could be drawn... The earthquake must have occurred after the sacrifice had been performed and prior to any attempt to remove the victim from the altar. The blood which had been collected in the buckets had already been offered to the cult idol, as similar vessels found in the central room testify, not to mention the blood-laden Kamares vase depicting a bull, the animal most usually sacrificed" ${ }^{\prime 37}$.

Bonnechere terms this account "la principale faille de l'hypothèse des Sakellarakis"38. In reality, however, the interpretation suggested by the excavators does not depend upon the detail of the bones' discolouration which is so fervently disputed; indeed, even if this contentious detail is removed entirely from consideration, it may be argued that a substantial case for a human sacrifice remains, since the interpretations of the evidence suggested by both Hughes and Bonnechere rest, essentially, upon a description of the accidental and the unlikely. The young man, it is supposed,

37 Ibid., p. 154.

38 BONNECHERE, loc. cit. (n. 33), p. 25 
accidentally fell upon the elevated area, and the blade accidentally fell upon him - in a manner, incidentally, already made familiar by Herodotus' account of Croesus' fears for his son Atys. Yet for those who may find the evidence from Anemospilia provoking but, like Hughes and Bonnechere, consider it less than compelling as proof of the practice of human sacrifice, one further alternative may be suggested: that the ritual which was interrupted by the earthquake was merely of a symbolic nature, a re-enactment perhaps of a mythical event. In this case it would be necessary to dismiss not merely the hypothesis that the victim died of blood loss rather than as a consequence of the collapse of the building, but also the excavators' suggestion that he was bound at the time of his death. However, for the purpose of the interpretation suggested here, it matters little whether there was an actual sacrifice occurring at the time of the earthquake or whether the events were merely symbolic, the mock wounding of the victim. For I propose that, on either interpretation, the discoveries at Anemospilia reveal the ritual enactment of the death of the god, of Zeus Kretagenes.

An important omission made by both of the critics of Sakellarakis is the possible significance of the location of the building described as a Minoan temple, on the slopes of Mt. Iouktas, and of the blade which was discovered lying across the torso of the supposed victim. The blade has been described by Sakellarakis thus ${ }^{39}$ : "The bronze weapon $(0.40 \mathrm{~m}$. long) belongs to a very rare type with a short handle and two holes in the middle. The few such weapons that have previously come to light were long classified as knives but recent research does not exclude the possibility that typologically they are, in fact, lances of some description. Depicted precisely in the middle of the lance on both sides is a cast and incised decoration of the head of a fantastic beast with erect ears like butterfly-wings, a long nose, and boar-like tusks. The eyes resemble a fox's while the whole animal is feline in character. Perhaps these various elements had been purposely chosen for symbolic reasons. The heads thus do not constitute a simple decorative motif but should be seen as an emblem". In fact, however, for all the attention paid in this description to the details of the ears and the eyes, it is the snout and the curved tusks which identify the creature incised on the blade as, quite unambiguously, a boar. Assuming that the blade was indeed the instrument of death or of mock-wounding, the iconography of the blade suggests that the young victim was put to death, in reality or symbolically, with a lance in the form of a boar, or, by a boar in the form of a lance. As was observed earlier, it was the shared fate of Adonis and Attis to die by being gored by a boar, with possibly the additional connotation of self-emasculation or emasculation by the boar. It was a fate which, to judge by the little detail which attaches to the supposed death of Zeus in Crete, was suffered by him also. It may therefore be reasonable to suggest that the blade depicting the

39 Sakellarakis \& Sapouna-Sakellaraki, op. cit. (n. 29), p. 154. 
boar's head associates the sacrificial victim with the violent deaths of these divine figures.

The location of the Anemospilia structure, on the northern slopes of Mt. Iouktas, may itself make a contribution to the significance of the discoveries made within it, in that the tradition of Zeus' burial in Crete came to be closely associated with that peak. There seems to be little room for doubt that the tradition of Zeus' burial there arose from the very appearance of the mountain, in that its outline, when viewed from the west, reveals the profile of a bearded head reclining as in sleep or in death. A.B. Cook ${ }^{40}$ has called

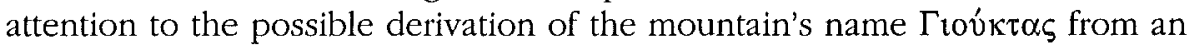
earlier form $\Delta \imath \hat{\omega} \kappa \tau \alpha \varsigma$, meaning 'the Pursuer'. He recalls that Callimachus' Hymn to Artemis ${ }^{41}$ describes the pursuit of Britomartis by the enamoured Minos; in an attempt to escape his clutches, she threw herself into the sea from a crag, but she was saved by the nets of some fishermen; and from that time Britomartis became known as Diktyna, Lady of the Nets, and the crag from which she jumped was known as Dikte, Hill of the Nets ${ }^{42}$. Cook has suggested the possibility that the pursuing Minos may himself in turn have been transformed into the mountain known as $\Delta \mathrm{l} \omega$ ' $\kappa \alpha \varsigma /$ louktas, 'The Pursuer', though he is unable to point to supporting evidence; and it may be possible to accommodate the association of the dying Zeus with Mt. Iouktas by suggesting that the Pursuer in fact refers to Zeus the Hunter who, like Adonis and Attis, was killed by his prey, the boar: but, as in Cook's suggestion, no supporting evidence can be adduced.

However, an alternative; and rather more convincing, etymology has been suggested by P. Faure ${ }^{43}$. Observing the tendency in the modern Cretan dialect for $\gamma 1 \alpha-\gamma 10-$ to replace $\delta 1 \alpha-\delta 10-$, and also its tendency to end the names of mountains in $-\alpha \varsigma$, Faure has suggested a derivation ${ }^{*} \Delta$ เov́ $\chi \theta \theta_{\varsigma}-* \Delta$ tov́ $\chi \theta \alpha \varsigma-$

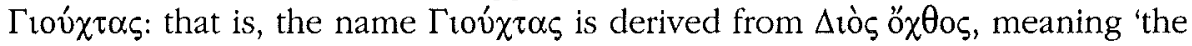
sacred mountain of Zeus'. In this case, Faure suggests, it is fruitless to seek, as so many have done, a cave or cairn on the mountain as the god's resting place; rather it is the entire mountain which was sacred to him, and beneath which, it was believed, he lay buried; and it was the appearance of the mountain, with its striking profile, which attracted to it the myth of Zeus' burial.

The case argued here is cumulative: that the worship of Zeus in Crete as a god who died, and was reborn, annually, was derived from the Minoan cult of a god of vegetation who similarly died and was reborn; that the (albeit

40 Cook, op. cit. (n. 18), ii, p. 939.

41 Callim., Hymns, 3, $190 \mathrm{f}$.

42 Diodonus $(V, 76,3)$ offers the same story, though he also includes an alternative version that she was called Lady of the Nets because she was a huntress, sometimes confused with Artemis herself.

43 Faure, loc. cit. (n. 20), p. 146-147. 
limited) evidence, that Zeus died by being torn by a boar, associates him as dying god with other vegetation gods, such as Adonis and Attis, who also were killed by a boar; that the death and burial of Zeus were associated with Mt. Iouktas because its profile represented the dead god reclining in death, and that the mountain thus took the name 'sacred mountain of Zeus'. It may thus be far from coincidental that it is on this same mountain that the remains were discovered of what has been termed by the excavators a human sacrifice, during the ritual of which the young male victim had been done to death with a blade bearing the representation of a boar. For many, it has been a cause of unease that the most substantial evidence for the practice of human sacrifice in Minoan Crete should have derived from such fortuitous circumstances: for had the ritual not been interrupted by the earthquake's devastation, the evidence would not have remained to be discovered. It was perhaps partly this unease which led the excavators themselves to draw the conclusion that the earthquake was the cause of the sacrifice. However, I suggest that the evidence of the location of the site and of the decoration of the blade argues that the occasion of the sacrifice, or of the mock-wounding, was considerably more important, and that consequently the discovery may have been even more fortuitous than has been supposed: that the earthquake interrupted the very ritual of the vegetation god's annual death, gored by the wild boar. I suggest that, during the time of the Mycenaeans' presence in Crete, the name of their supreme god, the IndoEuropean sky-god Zeus, came to be associated, quite inappropriately, with this ritual of the Minoans' dying god of vegetation; and that consequently there arose in Crete alone the tradition of the dying Zeus, for which the inhabitants of the island were subsequently condemned as liars by all other Greeks ${ }^{44}$.

N. Postlethwaite

Department of Classics and Ancient History

University of Exeter

EX4 4QH

UK

44 I am grateful to the Editorial Committee of Kernos for a number of helpful suggestions in the preparation of this paper. 